Original Article

\title{
Evaluation of methanolic crude extract of Linum usitatissimum for the removal of biofilm in diabetic foot isolates
}

\author{
Avaliação do extrato em bruto metanólico de Linum usitatissimum para remoção de \\ biofilmes em isolados diabéticos de pé
}

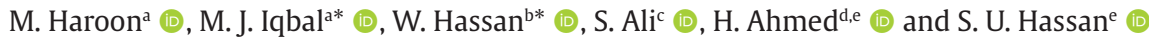 \\ aCOMSATS University Islamabad, Department of Chemistry, Lahore Campus, Lahore, Pakistan \\ ${ }^{\mathrm{b} C O M S A T S}$ University Islamabad, Department of Pharmacy, Lahore Campus, Lahore, Pakistan \\ 'Sargodha Medical College, Department of Biochemistry, Sargodha, Pakistan \\ dSialkot Medical College, Department of Pharmacology, Sialkot, Pakistan \\ eImran Idrees College of Pharmacy, Sialkot, Pakistan
}

\begin{abstract}
Linum usitatissimum $\mathrm{L}$ is a widely used traditionally for multiple ailments. The present research was carried out to explore the antimicrobial, and anti-biofilm activity of crude extract of Linum usitatissimum L ( $\mathrm{Lu}$. Cr). Phytochemical and proximate analyses were performed. The bandages of diabetic foot patients were collected from the various hospitals. The bandages were cultured to isolate the bacterial strains present on it. The disc diffusion method was used to identify the antimicrobial potential whereas the minimum inhibitory concentration of the Lu.Cr were also determined. Proximate analysis confirms moisture content $8.33 \%$, ash content $4.33 \%$, crude protein $21.20 \%$, crude fat $49.2 \%$ and crude fiber 5.63\%. It was revealed that Gram-positive bacteria are most prevalent among all study groups. Lu.Cr possess significant bactericidal potential against $S$. aureus among all other microbes. Owing to this potential, linseed coated bandages can be used alternatively for the treatment of diabetic foot.
\end{abstract}

Keywords: linseeds, antimicrobial activity, minimal inhibitory concentration, anti-biofilm activity.

\begin{abstract}
Resumo
Linum usitatissimum L é amplamente utilizado tradicionalmente para doenças múltiplas. O presente trabalho foi realizado para explorar a atividade antimicrobiana e antibiofilme do extrato bruto de Linum usitatissimum L (Lu.Cr). Foram realizadas análises fitoquímicas e aproximadas. As ataduras de pacientes diabéticos com pé foram recolhidas nos vários hospitais. As bandagens foram cultivadas para isolar as cepas bacterianas presentes nas mesmas. $\mathrm{O}$ método de difusão em disco foi utilizado para identificar o potencial antimicrobiano e a concentração inibitória mínima do Lu.Cr também foi determinada. A análise aproximada confirma o teor de umidade 8,33\%, teor de cinzas $4,33 \%$, proteína bruta $21,20 \%$, gordura bruta $49,2 \%$ e fibra bruta $5,63 \%$. Foi revelado que as bactérias Gram-positivas são mais prevalentes entre todos os grupos de estudo. Lu.Cr possui potencial bactericida significativo contra S. aureus entre todos os outros micróbios. Devido a esse potencial, as ligaduras revestidas com linhaça podem ser utilizadas alternativamente para o tratamento do pé diabético.
\end{abstract}

Palavras-chave: linhaça, atividade antimicrobiana, concentração inibitória mínima, atividade antibiofilme.

\section{Introduction}

The linseed or flaxseed belongs to the family "Linaceae". Currently, linseed fiber is used for making high grade writing paper, cigarette paper, and currency paper (Goyal et al., 2014). The most common constituent of Linum ustitatissimum is omega 3 fatty acids or ( $\alpha$-linolenic acid) ALA (Silva Stefani et al., 2019). Moreover, it contains about $30 \%$ proteins, ( $80 \%$ and $20 \%$ globulins and gluten respectively) (Arslanoğlu and Aytaç, 2020). Omega-3 fatty acids are found to very effective in chronic ailments such as cardiac diseases, nephrological and urological

disorders, diabetes mellitus, rheumatism and certain type of malignancies like prostate, breast and colonic (Dzuvor et al., 2018). Flaxseed also contains high-fat content, dietary fiber and protein but is poor in starch. It contains $30-41 \%$ fats, $20-35 \%$ dietary fiber, $20-30 \%$ protein, 4-8\% moisture, $3-4 \%$ ash and $1 \%$ simple sugars (Goyal et al., 2014). The main component of flaxseeds is oil (36-40\%).

Diabetes is one of the rapidly growing worldwide diseases and it imparts deteriorating effects on human health many comorbidities are associated with this

*e-mail: javidiqbal@cuilahore.edu.pk; waseemhassan2010@yahoo.com

Received: November 22, 2020 - Accepted: February 13, 2021 
debilitating disease. Most commonly diabetes causes nephropathy, neuropathy, cardiovascular disorders and diabetic foot (Yazdanpanah et al., 2015). About 15 to 25\% of diabetic patients are affected by foot ulcers (Kasiewicz and Whitehead, 2017). Microorganisms that are involved in the diabetic foot ulcers are Gram-positive microorganisms Staphylococcus aureus (S. aureus), Enterococcus, and Gram-negative microorganisms Pseudomonas aeruginosa (P. aeruginosa), Escherichia coli (E. Coli), proteus species (Banu et al., 2015). If the foot ulcers were not treated on time they lead to blood and gangrene infections, therefore proper precautionary measures should be adopted to treat foot ulcers (Madmoli et al., 2019).

Multi-microbial communities i.e. all types of microorganisms (bacteria, fungi, yeast, algae, and protozoa) that are present in the same area and are attached to biotic and abiotic surfaces are biofilms (Araújo et al., 2004). Most of the human body infections are due to these biofilm formations. Some of the biofilms play important and functional roles like intestinal microbiota. Whereas the usual and persuaded process for the lessening of bacterial biomass through the reduction of biofilm formation (Miquel et al., 2016).

The present research work was carried out to identify the possible antimicrobial effect of methanolic extract of Linum ustitatissimum (Lu.Cr) on the biofilm of the bandages of diabetic foot.

\section{Materials and Methods}

For testing diverse media, selective reagents, standard chemicals, and antibiotic discs were used to check sensitivity of isolated strains. All chemicals used were of analytical grade (Merck Laboratory and American Sigma Laboratories). Chemicals used included; normal saline, oxidase reagent, catalase reagent, hand sanitizer, Gram staining reagents, etc. Fresh Flaxseeds were collected from the local market and air-dried in an oven at a temperature $\left(40^{\circ} \mathrm{C}\right)$. Dried seeds were ground to powder form and stored in tightly closed plastic bottles to avoid moisture content.

The bandage scraps were collected from the patients of 100 diabetic foot cases 55 males and 45 females. The average number of bandages were 10 from every patient after every 5 days and observed that they contain several microorganisms on them. The inclusion criteria were the patients of 40 to 55 years. The patient should be diabetic for 1-10 years and the age of diabetic foot ulcers should be 5-30 days. No antibiotic should be started yet. About 35 percent of bandages showed no growth. Ethical approval of the study was obtained from the Comsats University Islamabad, Lahore Campus (Ethical approval number CIIT-20-112 dated 01-04-2020). Ethical approval was also obtained from the different institute/hospital from where the bandages were collected.

\subsection{Microbial cultures}

The bandages were collected from different hospitals and the puss present on the bandages were all together placed in petri dishes and identified microorganisms present on the bandages. The microorganisms were isolated and cultured from the wound bandages of the patients. The most prevalent microorganisms were E. coli, K. pneumonia, S. aureus, and P. aeruginosa. These cultures of these organisms were stored in microbiology lab for antimicrobial and minimal inhibitory concentration activities. The anti-biofilm activity was performed on the puss bandages of foot ulcers of diabetic patients by using Lu. $\mathrm{Cr}$ of different concentrations.

\subsection{Preparation of linseed crude extract}

The powdered form of Linum ustitatissimum ( 5 grams) was placed in a round bottom flask with $30 \mathrm{~mL}$ of $95 \%$ methanol and placed at room temperature for a week. This solution of linseeds was stirred frequently for a week and then filtrate was collected by Whatsman filter paper (Amin and Thakur, 2014).

\subsection{Proximate analysis}

Homogenized samples were used to analyze moisture content, protein content, fat content, ash content, and fiber content by the methods explained by (Shahid et al., 2020)

\subsection{Disc diffusion susceptibility method}

The antimicrobial activity of the methanolic extract of linseed was determined by disc diffusion susceptibility method. Different antibiotics (Penicillin (P) $10 \mu$ g Cefpirome (CPO) $30 \mu \mathrm{g}$ Vanomycin (VA) $30 \mu \mathrm{g}$ Amoxycillin (AMC) $30 \mu \mathrm{g}$ ) were used and carefully placed on the agar plates. The plates were then placed in an incubator for 24 hours at $37^{\circ} \mathrm{C}$. Zone of inhibitions were developed against each antibiotic and the linseed extract (Alahmad et al., 2018).

\subsection{Minimal Inhibitory Concentration (MIC)}

Minimal Inhibitory concentration was measured by taking the plant crude extract in different concentrations on the agar plates. These plates were then incubated for 24 hours in an incubator at $37^{\circ} \mathrm{C}$. The results were observed on the plates as a different zone of inhibitions against each microorganism (Shad et al., 2016).

\subsection{Antibiofilm activity}

The antibiofilm activity was demonstrated against the wounds of diabetic foot patients. The bandages of these patients were taken from different hospitals in Lahore. Mixed culture growth of different microorganisms was observed on these bandages and was taken on the 96 well microtiter plates. Dilutions ( $12.5 \mathrm{mg} / \mathrm{mL}, 25 \mathrm{mg} / \mathrm{mL}$, and $50 \mathrm{mg} / \mathrm{mL}$ ) of the extract were also placed on these plates. These plates were incubated at $37{ }^{\circ} \mathrm{C}$ for 24 hours. The results were then observed on microtiter plate reader. (Al-Mathkhury et al., 2016).

\section{Statistical Analysis}

The results were evaluated by using one-way ANOVA and then followed by Tukey's Test. The results were mainly considered significant $\left({ }^{*}\right)$ if $\mathrm{p}<0.05,\left({ }^{* *}\right) \mathrm{p}<0.001$, more significant $\left({ }^{* * *}\right)$ if $\mathrm{p}<0.0001$. 


\section{Results}

Proximate analysis showed that the methanolic extract of Linum ustitatissimum had moisture content of 8.3\%, ash content $4.33 \%$, crude protein $21.20 \%$, crude fat $49.2 \%$, and crude fiber $5.63 \%$ (Table 1 ). The results confirmed higher crude fat and crude protein content and low values of fiber, ash and moisture content.

\subsection{Antimicrobial activity}

Different zone of inhibitions was observed with different antibiotics and microbes. Revealing that it has significant effect on S. aureus and the least effect on K. pneumonia. It means that linseeds are effective against $S$. aureus while other microbes were not effective against linseed extract as shown in Figure 1.

\subsection{Minimal inhibitory concentrations}

The effect of the Li.Cr on different microorganisms by changing the concentration (10 to $120 \mathrm{mg} / \mathrm{mL}$ ) was observed. The following results have shown that $S$ aureus has the best results at a minimum concentration $(120 \mathrm{mg} / \mathrm{mL})$. $S$ aureus inhibited the growth of microorganisms at the minimum concentration extract as shown in Figure 2.

\subsection{Antibiofilm activity}

These results showed the effect of pure linseed extract and its comparison with different concentrations to affect microorganisms (Table 2). It had observed that the Li.Cr has a great inhibitory effect on bacteria. $S$ aureus gave the maximum inhibitory effect with a concentration of $12.5 \mathrm{mg} / \mathrm{mL}$ and the mean value for it was 0.043 whereas the minimum effect was observed against $K$. pneumonia with a mean value of 0.00715 as shown in Figure 3.

\section{Discussion}

Seeds of Linum ustitatissimum are an excellent source of functional food ingredients i.e. moisture, ash, crude fat, crude protein and crude fiber. As Linseeds have a high fat and protein content, it helps in strengthening

Table 1. Proximate composition of Linum ustitatissimum.

\begin{tabular}{lcccc}
\hline \multicolumn{1}{c}{ Factors } & \multicolumn{3}{c}{ Linum ustitatissimum } & Mean \\
\hline Moisture (\%) & 8.6 & 8.3 & 8.0 & 8.3 \\
Ash (\%) & 4 & 5 & 4 & 4.33 \\
Protein (\%) & 19.28 & 21.89 & 22.44 & 21.20 \\
Fat (\%) & 50.70 & 46.58 & 50.32 & 49.2 \\
Fiber (\%) & 5.1 & 6.6 & 5.2 & 5.63 \\
\hline
\end{tabular}

our immune system. Infectious diseases are caused by the microorganisms like bacteria fungus and viruses, these diseases are communicable and spread in the community (Nascimento et al., 2000; Badiger et al., 2019; Naerender et al., 2016). Diabetic foot ulcers are a troublesome disease. Many diabetic patients suffer from this disease because of the microvasculature of the extremities and neuropathy. Due to hyperglycemia the diameter of the vasculature is significantly decreased and peripheral neuropathy causes the loss of sensation in the extremities especially in the feet. It mostly occurs in those patients who have uncontrolled diabetes mellitus (Fadzir et al., 2018). The present study explains the antimicrobial potential of

A
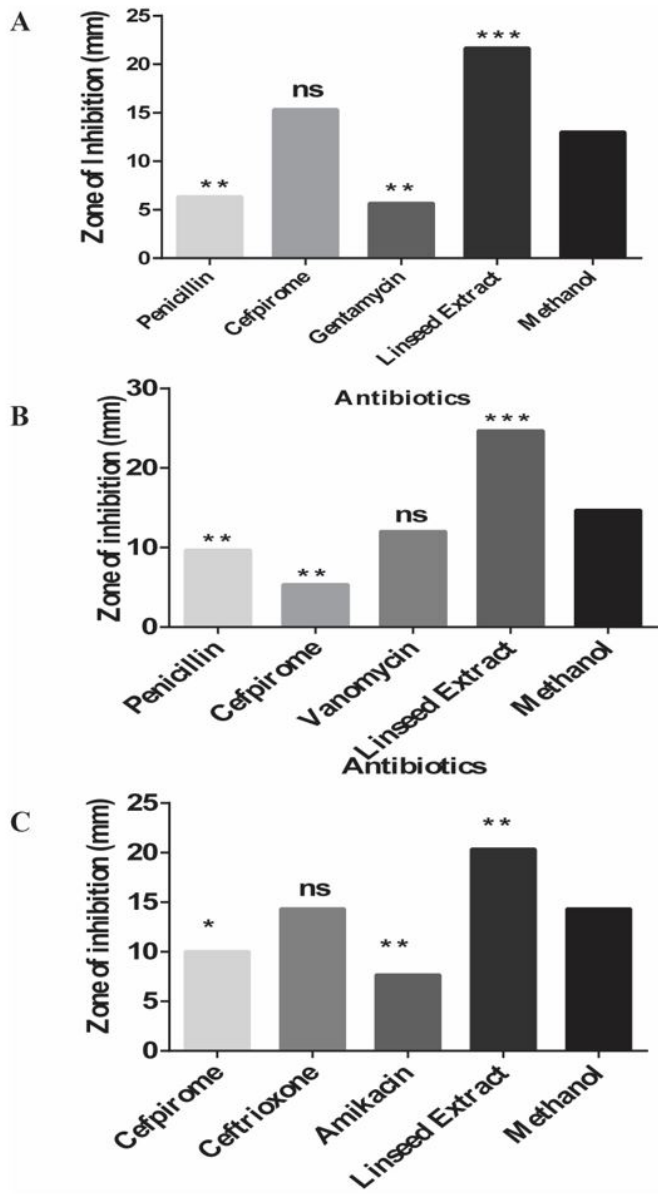

Figure 1. Inhibitory effect of flaxseed extract on bacterial isolates. (A) E. coli, (B) S. aeureus (C) K. pneumonia. The results were mainly considered significant $\left({ }^{*}\right)$ if $\mathrm{p}<0.05,\left({ }^{* *}\right) \mathrm{p}<0.001$, more significant $\left({ }^{* * *}\right)$ if $\mathrm{p}<0.0001$, while non-significance is denoted by "ns".

Table 2. Showing the prevalence of each bacteria in the observed bandages.

\begin{tabular}{ccccccc}
\hline $\begin{array}{c}\text { Number of } \\
\text { patients }\end{array}$ & $\begin{array}{c}\text { Number of } \\
\text { bandages }\end{array}$ & No growth & E. coli & K. pneumonia & S. aureus & P. aeruginosa \\
\hline 106 & 1060 & 212 & 173 & 212 & 365 & 98 \\
\hline
\end{tabular}


A

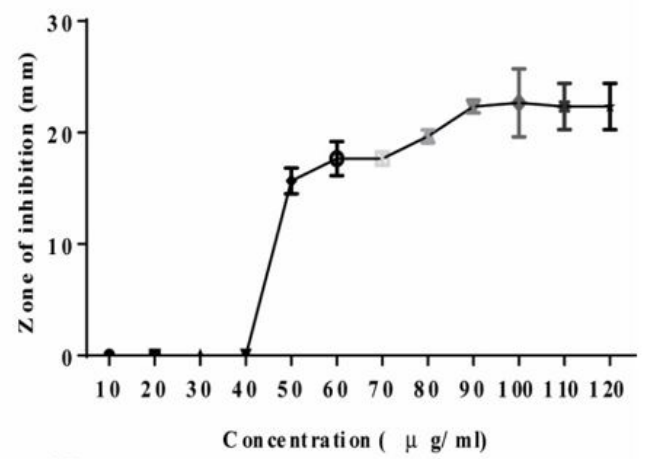

B

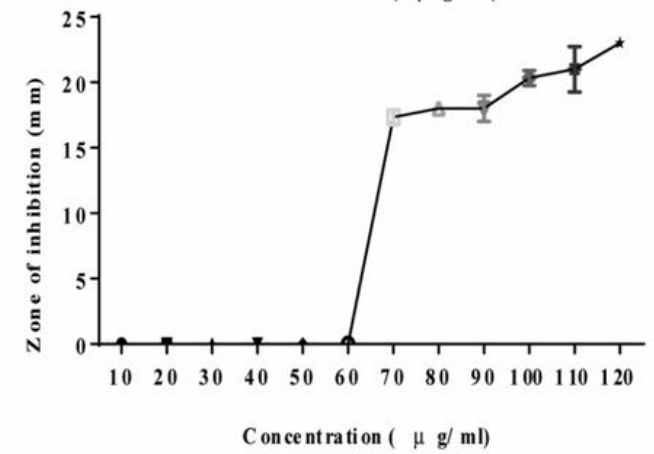

C

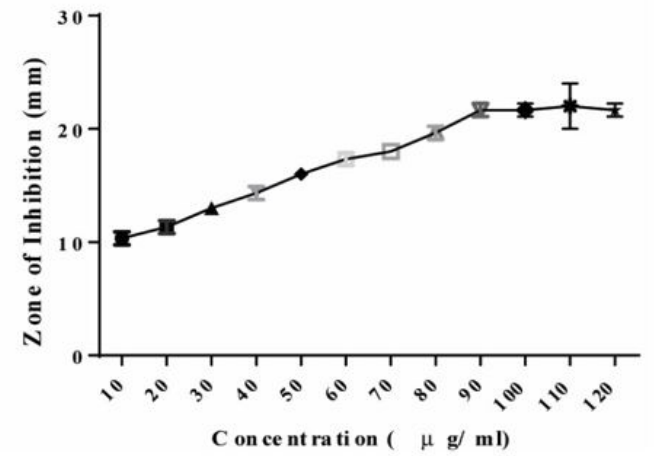

Figure 2. MIC Values of Lu.Cr 10 to $120 \mu \mathrm{g} / \mathrm{mL}$ A (E. coli) B (S. aeureus) C (K. Pneumonia).

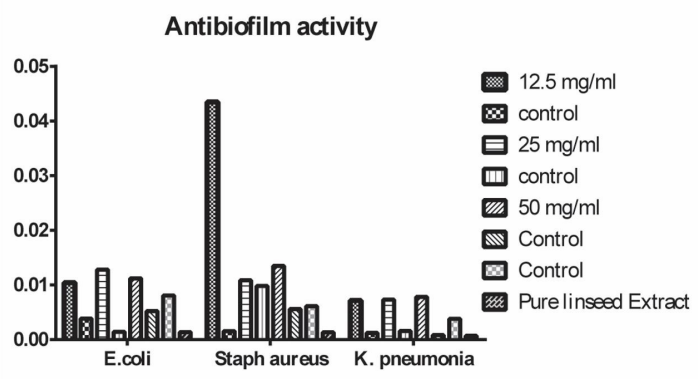

Figure 3. Effect of Linseed on microorganisms with different concentrations.

Lu.Cr against the bacteria like E.coli, S. aureus, K. pneumonia. Antimicrobial activity was evaluated by measuring the diameter of zone of inhibition of different microbes. The maximum antimicrobial activity was observed against gram positive bacteria i.e. S. aureus. The antimicrobial profile of Lu.Cr against tested bacteria indicated E. coli, K. pneumonia was the most susceptible one. It has been observed that linseed have the antimicrobial activity against gram positive bacteria whereas they are less effective against gram negative bacteria (Fadzir et al., 2018; Gaafar et al., 2013; Homman, 2018). Many experiments showed the antimicrobial effect of various microbes.

MIC is the lowest drug inhibitory concentration that prevents the growth of a microorganism after incubation of 24 hours (Shaban et al., 2020).

Bacteria that grow as biofilm encased in a self-produced matrix and protected from host defenses and often exhibited reduced antibiotic susceptibility contributing to the persistence of biofilm infections (Wang et al., 2009). Biofilm inhibition is considered a major drug target for the treatment of many bacterial infections (Sánchez et al., 2016). The microorganisms were isolated in laboratory and concluded that they contain gram-positive and gram-negative microorganisms. They were treated by using linseed extract. E. coli show low antibiofilm activity as compared to other microbes whereas $S$. aureus showed the best antibiofilm activity results (Bazargani and Rohloff, 2016).

\section{Conclusion}

Anti-biofilm activity was observed against many microbes present on the bandages of diabetic foot ulcers. It was revealed that $S$. aureus showed the best results against Lu.Cr while $E$. coli had a minimum effect against extract. Finally, it is plausible to conclude that the linseed containing bandages could help to achieve more therapeutic killing effect against the topical Gram-positive bacteria.

\section{References}

ALAHMAD, B.E.M., KASHMOOLA, M.A., KUMAR, P., SUBRAMANIAM, L., MOKHTAR, K.I.B. and SHABAN MUSTAFA, N., 2018. The antibacterial effect of flaxseed extract on selective oral pathogens: comparative in vitro study. World Journal of Pharmacy and Pharmaceutical Sciences, vol. 7, no. 11, pp. 1-11.

AL-MATHKHURY, H.J.F., AL-DHAMIN, A.S. and AL-TAIE, K.L., 2016. Antibacterial and antibiofilm activity of flaxseed oil. Iraqi Journal of Science, vol. 57, no. 2B, pp. 1086-1095.

AMIN, T. and THAKUR, M., 2014. A comparative study on proximate composition, phytochemical screening, antioxidant and antimicrobial activities of Linum usitatisimum L. (flaxseeds). International Journal of Current Microbiology and Applied Sciences, vol. 3, no. 4, pp. 465-481.

ARAÚJO, P., OLIVEIRA, G., CÓRDULA, C., LEITE, E., CARVALHO JUNIOR, L. and SILVA, M., 2004. Sulfated fucan as support for antibiotic immobilization. Brazilian Journal of Medical and Biological Research, vol.37, no. 3, pp. 301-305. http://dx.doi.org/10.1590/ S0100-879X2004000300002. PMid:15060694.

ARSLANOĞLU, S.F. and AYTAÇ, S., 2020. The important of flax (Linum usitatissimum L.) in terms of health. International Journal of Life Sciences and Biotechnology., vol. 3, no. 1, pp. 95-107. http:// dx.doi.org/10.38001/ijlsb.690295. 
BADIGER, A.B., GOWDA, T.M., RAJARAJESHWARI, S., SASWAT, S., MAJHI, T.K. and MEHTA, D., 2019. Antimicrobial effect of flaxseed (Linum usitatissimum) on periodontal pathogens: an in vitro study. International Journal of Herbal Medicine, vol. 7, no. 3, pp. 16-19.

BANU, A., HASSAN, M.M.N., RAJKUMAR, J. and SRINIVASA, S., 2015. Spectrum of bacteria associated with diabetic foot ulcer and biofilm formation: a prospective study. The Australasian Medical Journal, vol. 8, no. 9, pp. 280-285. http://dx.doi.org/10.4066/ AMJ.2015.2422. PMid:26464584.

BAZARGANI, M.M. and ROHLOFF, J., 2016. Antibiofilm activity of essential oils and plant extracts against Staphylococcus aureus and Escherichia coli biofilms. Food Control, vol. 61, pp. 156-164. http://dx.doi.org/10.1016/j.foodcont.2015.09.036.

DZUVOR, C.K.O., TAYLOR, J.T., ACQUAH, C., PAN, S. and AGYEI, D. 2018. Bioprocessing of functional ingredients from flaxseed. Molecules, vol. 23, no. 10, pp. 2444. http://dx.doi.org/10.3390/ molecules23102444. PMid:30250012.

FADZIR, U.A., DARNIS, D.S., MUSTAFA, B.E. and MOKHTAR, K.I., 2018. Linum usitatissimum as an antimicrobial agent and a potential natural healer: a review. Archives of Orofacial Science, vol. 13, no. 2, pp. 55-62.

GAAFAR, A.A., SALAMA, Z.A., ASKAR, M.S., EL-HARIRI, D.M. and BAKRY, B.A., 2013. In vitro antioxidant and antimicrobial activities of Lignan flax seed extract (Linum usitatissimum L.). International Journal of Pharmaceutical Sciences Review and Research, vol. 23, no. 2, pp. 291-297.

GOYAL, A., SHARMA, V., UPADHYAY, N., GILL, S. and SIHAG, M., 2014. Flax and flaxseed oil: an ancient medicine \& modern functional food. Journal of Food Science and Technology, vol. 51, no. 9, pp. 1633-1653. http://dx.doi.org/10.1007/s13197013-1247-9. PMid:25190822.

HOMMAN, W.A.A.M.M., 2018. Evaluation of antimicrobial activity of linseed (Linum usitatisimum) on different types of bacteria. Iraq: University of Basrah.

KASIEWICZ, L.N. and WHITEHEAD, K.A., 2017. Recent advances in biomaterials for the treatment of diabetic foot ulcers. Biomaterials Science, vol. 5, no. 10, pp. 1962-1975. http://dx.doi. org/10.1039/C7BM00264E. PMid:28829074.

MADMOLI, M., MADMOLI, Y., KHODADADI, M. and SAMSAMIPOUR, M., 2019. Study of some effective treatments for accelerating diabetic foot ulcer Healing. International Journal of Research Studies in Science, Engineering and Technology, vol. 6, no. 2, pp. 34-39.

MIQUEL, S., LAGRAFEUILLE, R., SOUWEINE, B. and FORESTIER, C., 2016. Anti-biofilm activity as a health issue. Frontiers in Microbiology, vol. 7, pp. 592. http://dx.doi.org/10.3389/ fmicb.2016.00592. PMid:27199924.

NAERENDER, B.R., TEJASWINI, S., SARIKA, M., KARUNA, N., SHIRISHA, R. and PRIYANKA, S., 2016. Antibacterial and antifungal activities of Linum usitatissimum (Flax seeds). International Journal of Pharmaceutical Education and Research, vol. 3, pp. 4-8.

NASCIMENTO, G.G., LOCATELLI, J., FREITAS, P.C. and SILVA, G.L., 2000. Antibacterial activity of plant extracts and phytochemicals on antibiotic-resistant bacteria. Brazilian Journal of Microbiology, vol. 31, no. 4, pp. 247-256. http://dx.doi.org/10.1590/S151783822000000400003.

SÁNCHEZ, E., RIVAS MORALES, C., CASTILLO, S., LEOS-RIVAS, C., GARCÍA-BECERRA, L. and ORTIZ MARTÍNEZ, D.M., 2016. Antibacterial and antibiofilm activity of methanolic plant extracts against nosocomial microorganisms. Evidence-Based Complementary and Alternative Medicine, vol. 2016, 1572697. http://dx.doi.org/10.1155/2016/1572697. PMid:27429633.

SHABAN, S.N., MOKHTAR, K.I., ICHWAN, S.J.A. and AL-AHMAD, B.E.M., 2020. Potential effects of flaxseed (Linum usitatissimum) in tissue reparative processes: a mini review. Journal of Biomedical Clinical Sciences, vol. 5, no. 1, pp. 1-7.

SHAD, A.A., ASMAT, S., BAKHT, J., JAN, S. and KHAN, M.A., 2016. Antimicrobial potentials and phytochemical analysis of desert cotton (A. Javanica) and flax (L. Ustitatissimum). Pakistan Journal of Pharmaceutical Sciences, vol. 29, no. 3, pp. 861-868. PMid:27166531.

SHAHID, M., FATIMA, H., ANJUM, F. and RIAZ, M., 2020. Proximate composition, antioxidant activities and fatty acid profiling of selected mushrooms collected from Azad Jammu and Kashmir. Acta Poloniae Pharmaceutica-Drug Research, vol. 77, no. 1, pp. 145-153. http://dx.doi.org/10.32383/appdr/112584.

SILVA STEFANI, F., CAMPO, C., PAESE, K., GUTERRES, S.S., COSTA, T.M.H. and FLÔRES, S.H.J.F.R.I., 2019. Nanoencapsulation of linseed oil with chia mucilage as structuring material: characterization, stability and enrichment of orange juice. Food Research International, vol. 120, pp. 872-879. http://dx.doi. org/10.1016/j.foodres.2018.11.052. PMid:31000308.

WANG, X., YAO, X., ZHU, Z., TANG, T., DAI, K., SADOVSKAYA, I., FLAHAUT, S. and JABBOURI, S., 2009. Effect of berberine on Staphylococcus epidermidis biofilm formation. International Journal of Antimicrobial Agents, vol. 34, no. 1, pp. 60-66. http:// dx.doi.org/10.1016/j.ijantimicag.2008.10.033. PMid:19157797.

YAZDANPANAH, L., NASIRI, M. and ADARVISHI, S., 2015. Literature review on the management of diabetic foot ulcer. World Journal of Diabetes, vol. 6, no. 1, pp. 37-53. http://dx.doi.org/10.4239/ wjd.v6.i1.37. PMid:25685277. 